\title{
Distinguishing females of capuchino seedeaters: call repertoires provide evidence for species-level diagnosis
}

\author{
Márcio Repenning ${ }^{1,2} \&$ Carla Suertegaray Fontana ${ }^{1}$
}

${ }^{1}$ Laboratório de Ornitologia, Museu de Ciências e Tecnologia, Programa de Pós-graduação em Ecologia e Evolução da Biodiversidade, Pontifícia Universidade Católica do Rio Grande do Sul, PUCRS, Porto Alegre, RS, Brazil.

2 Corresponding author: mrepenning@gmail.com

Received on 17 September 2018. Accepted on 03 May 2019.

\begin{abstract}
Reliable identification of cryptic Neotropical capuchino seedeater females remains as a recurrent and non-trivial issue in field ornithology. Even in the hand, capuchino females cannot be accurately diagnosed to the species level based solely on visual plumage examination, which may present a problem for future research on this group. During 10 years of field research on this group, we observed subtle vocal differences. We studied females of two parapatric species that may breed in syntopic upland grassland areas in southern Brazil: Tawny-bellied Seedeater Sporophila hypoxantha and Black-bellied Seedeater Sporophila melanogaster. Our main aim was to measure dissimilarities between inter-specific and intersexual repertory calls. We found unequivocal inter-specific divergences in call type repertoires revealed by cluster analysis, and no intersexual differences in the co-specific repertoire calls. These combined results enhance the understanding about the role of repertoire calls on species-specific recognition and interbreeding isolation processes (assortative mating), and provide a way to overcome the problem of field identification of female capuchinos at the species level.
\end{abstract}

KEY-WORDS: acoustic communication, assortative mating, bioacoustic, songbirds, Sporophila, vocal repertory.

\section{INTRODUCTION}

Females of the Neotropical genus Sporophila are very cryptic, which has limited field research in this group. The absence of morphological divergence and a uniform dull brownish plumage, which is common among females in this genus, make the study of this group very challenging (Meyer de Schauensee 1952, Ridgely \& Tudor 1989, Ouellet 1992, Sick 1997, Areta et al. 2011, Rising et al. 2011).

Currently, there are ten Sporophila (i.e., capuchino) seedeater species, all derived from a common ancestor (Campagna et al. 2015, Di Giacomo \& Kopuchian 2016). Species within this clade vary little in morphology and size and are notably sexually dimorphic in the coloration of their plumage, with males typically being colorful while females are brownish (Ridgely \& Tudor 1989). Despite inter-specific differences based on adult male plumage and song, genomic variation between capuchino seedeaters is minimal (Campagna et al. 2017), exemplifying the recent radiation of this Neotropical passerines (e.g., Campagna et al. 2010, Burns et al. 2014). As incipient species, some inconsistencies exist in the identification of the capuchinos: hybridization, aberrant plumages, color morphs, individual and seasonal variation of plumage color, and lack of diagnosis of the female by visual observation (Sick 1963 \& 1967, Short-Jr. 1969, Ouellet 1992, Areta 2008, Repenning et al. 2010b, Areta et al. 2011, Areta \& Repenning 2011).

Despite improvements in our knowledge of the taxonomy and ecology of Sporophila species in the last decade, the diagnosis of females remains uncertain. A single attempt to find a differentiation among females of capuchino species was based on the wavelength reflected from their plumage, which did not refute the hypothesis of simply the limitation of human vision (Benites et al. 2010). However, researcher has yet to resolve the subject of species-level diagnosis of female capuchino. As a result, there is still no detailed analysis to objectively determine female capuchino, perhaps because of our sensorial limitations in detecting and assimilating the slight differences in their voices. Conversely, based on previous experience, we suspect that female call types differ among species. We believe that the ability to successfully identify capuchino female's voice would open a new window into research on the behavioral ecology, evolution and taxonomy of Neotropical seedeaters (Odom \& Benedict 2018). Additionally, it could have positive implications for the conservation of threatened species of capuchinos, helping authorities identify specimens in female plumage that are confiscated from the illegal pet trade (e.g., females, first year males and males in complete "eclipse" plumage). 
Besides the importance of making the correct diagnosis of Sporophila females at the species level in the field, mapping their sex-specific voice repertoires would provide a new approach to study species-specific recognition and assortative mating (Paterson 1985, Slabbekoorn \& Smith 2002). Sexual selection that operates on traits used to transmit information to rivals and potential mates is an important driver in the evolution of passerines (Irwin et al. 2000). Sporophila capuchinos, besides using visual signals, may use simple vocal signals as premating barriers, thus maintaining differences between incipient species (Price 2008).

Here, we present a new way to diagnose visually indistinguishable capuchino females. We studied two migratory capuchino species, Tawny-bellied Seedeater and Black-bellied Seedeater, which breed mostly in allopatry and also in narrow contact zones in southern Brazilian grasslands (Repenning et al. 2010a). Our main aim was to evaluate whether capuchino females that are members of closely-related species differ vocally when breeding in contact zones. To address that question, we aimed to (1) provide an objective method for species-level diagnosis of Sporophila females, testing for differences in the repertories of calls; and (2) tested whether there is intraspecific, sex-based variation in contact call repertoires. Finally, we discuss the role of calls in assortative mating in the genus Sporophila.

\section{METHODS}

\section{Study species and site}

We studied two long-distance migratory species of the capuchino group: Tawny-bellied Seedeater Sporophila hypoxantha, and Black-bellied Seedeater Sporophila melanogaster. These species segregate spatially from each other throughout an environmental gradient (altitude and habitat) in the inner Planalto Meridional Brasileiro (Repenning et al. 2010a; Fig. 1). Sporophila melanogaster is common in the highest eastern grasslands (average $1000 \mathrm{~m}$ a.s.l.) and $S$. hypoxantha occurs in western valleys or at lower altitudes. They are the smallest among the Sporophila seedeaters species with total length of -98.0 $\mathrm{mm}$ and a body mass of $\sim 8.8 \mathrm{~g}$ (Franz \& Fontana 2013, Fontana \& Repenning 2014). The distinguishable plumage color of the adult male in breeding season was the primary criteria for the selection of these two species, because the unequivocal diagnosis of males was an assumption for this study.

Current knowledge about the pattern of the breeding ranges of both species was secondarily relevant. We carried out 10 years (2008-2018) of fieldwork in broad upland grassland localities in southern Brazil, including breeding areas of complete allopatry and areas of syntopy of both species, across five contact zone areas (Fig. 1, Table S1).

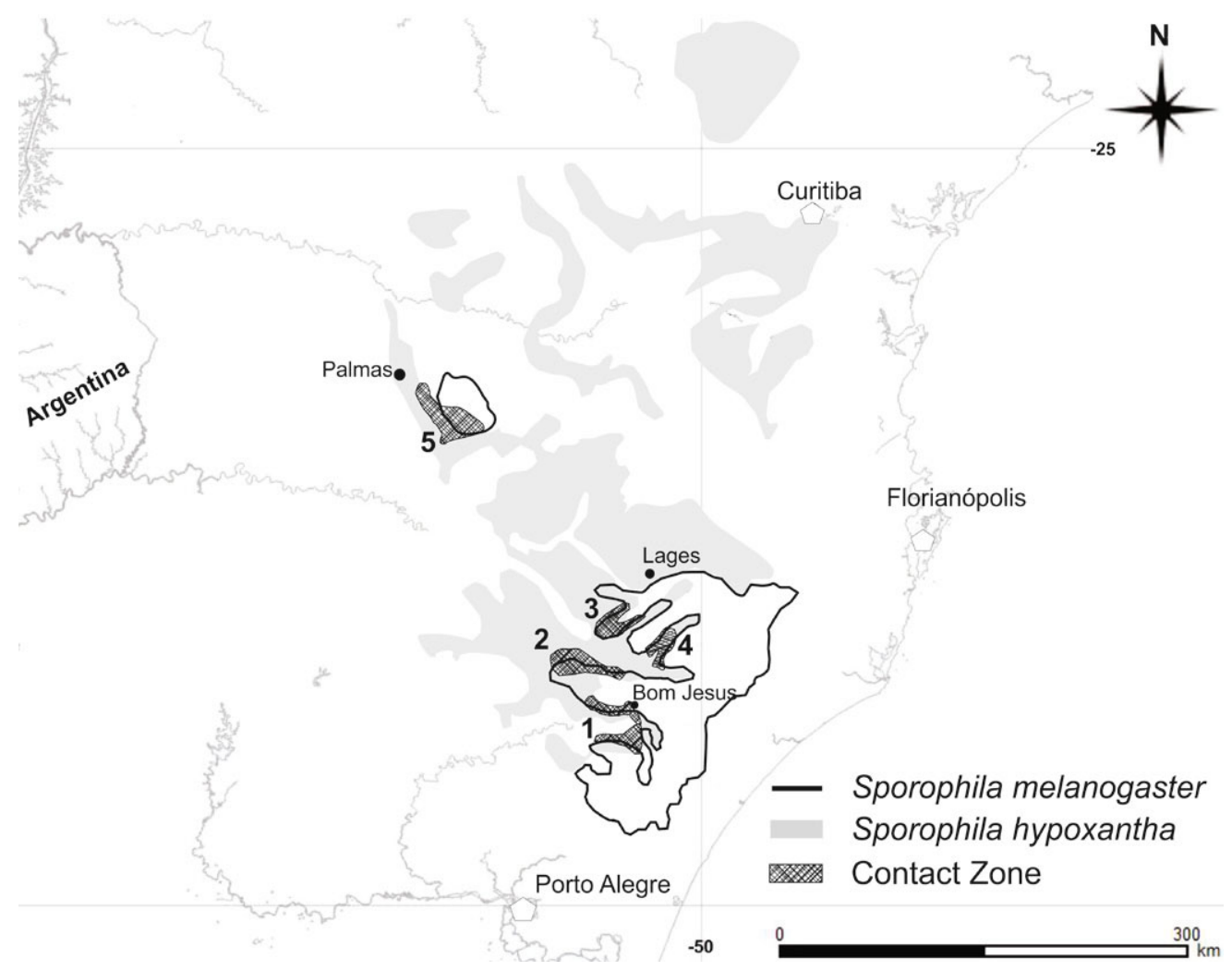

Figure 1. Breeding range of Sporophila melanogaster (solid black line) and S. hypoxantha (grey polygons) in the southern Brazilian highlands. Hachured polygons are five areas identified in situ as contact (hybrid) zones. Distributional limits were inferred based on a potential distribution estimates model, using the author's bird nesting records (Fig. S1 \& S2). 


\section{Definitions}

Allopatric areas are the localities where only males of pure phenotype (plumage and song) of each species were recorded breeding. The contact (hybridization or introgression) zones are the areas in which we recorded nesting activity of coupled males of both species with a breeding territory in contiguous areas, and breeding simultaneously, i.e., in syntopy. Males with a non-pure phenotype were also documented in these syntopic areas, suggesting some level of introgression of plumage characteristics. We recorded some of these males, but we did not include them in the sound analysis.

\section{Field recording and alarm call behavior}

The recording of capuchino female songs occurred after a rigorous identification of the social mate of each female, by observing mate-guarding behavior. Only recordings of females that were associated with evidence of breeding (e.g., incubating, taking care of nestlings or newly fledglings) were considered. We recorded vocalizations under a standardized close range to the focal bird $(\sim 10$ $15 \mathrm{~m}$ ) using Sony TC-D5M recorder and Nagra LB, Tascam DR-680 or Sony PCM-D50 digital recorders, with Sennheiser ME66 or ME62 external microphones associated with a Telinga parabola (21.5in/6.1in). All sounds recorded will be archived at the Macaulay Library of Natural Sounds (e.g., ML111751281), Cornell Lab. of Ornithology (Ithaca, NY). Territorial males and females were captured with an Ecotone mist net $(16 / 20 \mathrm{~mm})$ for color and metal banding. We banded all birds caught for individual identification and to prevent sample replication (Roos 2010).

\section{Sound processing and call definitions}

We consider a call type the unity of sounds that can be constituted by a single long note, a short note or syllables, i.e. a building block of songs or a regularly grouped combination of multiple whistled notes produced as a common unit (Baptista 1996, Hagemeyer et al. 2012). The very fast (shorter) calls we named chirps. We first classified each call type based on visual inspection of discrete categories under the temporal-spectral shape of the spectrogram. Calls were assumed as the same type when they were consistently equivalent in duration and frequency range, in their starting and ending frequencies, and in their frequencies at inflection points (Hagemeyer et al. 2012). Secondly, we built a reference collection with labeled sequential call types. For calls that were more difficult to discriminate, the Cross-Correlation analysis was also used, and slow-speed playback was used to help solving specific doubts. Such an analytical tool is an efficient way to measure similarities between short vocal elements over time and recorded sound quality with regard to signal-to-noise contrast (Bioacoustic Research Program 2004). We assumed that pairs of call types had the same sound element or note correlation when they had values higher than 0.7. Definition of sound units may be difficult due to the characteristic of continuity or discontinuity of each typical vocal element in oscine passerines (Lynch 1996). Therefore, we used analytical tools in a complementary way, aiming to reduce subjectivity regarding the discrete limits of each vocal element (Horn \& Falls 1996). Classic experiments have shown that the shape note or syllable within the repertoire in passerines can be a functional signal, with a more important role in species-specific recognition than syntax or the structural characteristics of the voices (Bremond 1976, Catchpole \& Slater 2008). Hence, understanding the extension of the similarity of call repertoires would allow us to assess the role of acoustic communication on assortative mating among closely-related capuchino species.

An evaluation of the scanned recordings was based on an analysis of the spectrogram, using a frequency resolution of $172 \mathrm{~Hz}$ and a time resolution of $2.3 \mathrm{~ms}$, generated with RAVEN Pro 1.5 software. We selected individual call types automatically (Band Limiter Energy Detector - BLED) using the following configuration: minimum frequency of $1076 \mathrm{~Hz}$, maximum of $6696 \mathrm{~Hz}$, minimum duration of $0.0243 \mathrm{~s}$, maximum of $0.855 \mathrm{~s}$ and a minimum separation of $0.0087 \mathrm{~s}$ in Target Signal Parameters. Other parameters followed the default configuration. After the detector interaction, another visual review was carried out to certify that heterospecific notes were not selected. This procedure was applied for each recorded individual. Lastly, each call type was labeled directly in a BLEDs interaction result table.

\section{Statistical analysis}

The recording sample available for analyses comprised a total of 1021 and 527 selected call types recorded in allopatry and syntopy, respectively, for $S$. hypoxantha ( $n$ $=32$ females, $n=24$ males), and 946 and 481 selected call types recorded in allopatry and syntopy, respectively, of $S$. melanogaster ( $n=25$ females, $n=16$ males). Frequency contour measurements were designed through spectrogram pitch tracking, which uses the dominant frequency value of a sound over time. The chosen tool to do this was the Frequency Contour Percentile 50\% $(\mathrm{Hz})$ which selects the frequency values $(\mathrm{Y}$ axis) through time ( $\mathrm{X}$ axis), and amplitude ( $\mathrm{Z}$ axis = grayscale in the spectrogram).

A distance matrix was built using aligned call types, in which each column represents a set of calls from a unique specimen. Each call type represents a sequential 
pitch frequency (shape note) set of values, i.e., frequency contour measurements $(\mathrm{Hz})$. We ran Bray-Curtis Cluster Analysis (Single Link) in BioDiversity Pro (McAleece 1997). Only specimens with a bias to stabilize the repertoire were analyzed. For each individual we used an average of three calls of each call type, aiming to understand the extent of intra-individual variation in calls. After assessing this variation in calls and realizing that it was smaller than that of the inter-individual calls, we selected only one call type to describe the individual repertoire that was used in the final similarity analysis.

\section{RESULTS}

\section{Repertoire accumulation}

The time over which the call types were revealed in successive voice recordings for each female is illustrated in Fig. 2. Female call type accumulation curves reached an asymptote in approximately 12 to 25 of the recorded calls. There was also variation in the rate in which females produced different call types, with some females exhibiting the full repertoire within the first eight recorded calls, whereas others required more than 30 calls to present and equivalent-sized call type repertoire (Fig. 2).

\section{Female call type repertoire}

The size of call type repertoires was similar between both species, with each female of $S$. melanogaster and
S. hypoxantha having an average of 6 (4-9) and 7 (3-8) call types, respectively. Also, females of $S$. melanogaster and $S$. hypoxantha often issued fast calls, with two and three chirps, respectively. Some calls were produced by almost every female (e.g., calls 4, 6 and 8 of S. hypoxantha, and calls 14 and 16 of $S$. melanogaster). Some call types (e.g., 1 and 18; Fig. 3) were rarely produced by females of either species. Female call types corresponded to male call type repertoire in both species. Nevertheless, male $S$. melanogaster calls have two notes that are absent in the repertoires of co-specific females (e.g., call types 19 and 20) (Fig. 3).

\section{Intra and inter-specific repertoire variation}

The cluster analysis of male and female $S$. melanogaster and $S$. hypoxantha repertoires revealed a dichotomy of species-level call repertoires (Fig. 4). We did not find any shared calls in the repertories of either species, even in the syntopic population. Additionally, no female coupled with a $S$. melanogaster male presented a repertoire of pure call types exhibited by $S$. hypoxantha, or vice versa. We found no intersexual divergence in call types because males and females did not present a clear intra-specific sub-cluster within the two larger clusters observed for $S$. melanogaster and $S$. hypoxantha (Fig. 4). Finally, we found that note types used by males in advertising songs were also used as contact/alarm calls by their co-specific females $(S$. melanogaster males [songs] and females [call repertory] shared $50 \%$ of note types and $S$. hypoxantha males [songs] and females [call repertory] shared 43\%; Fig. 3).
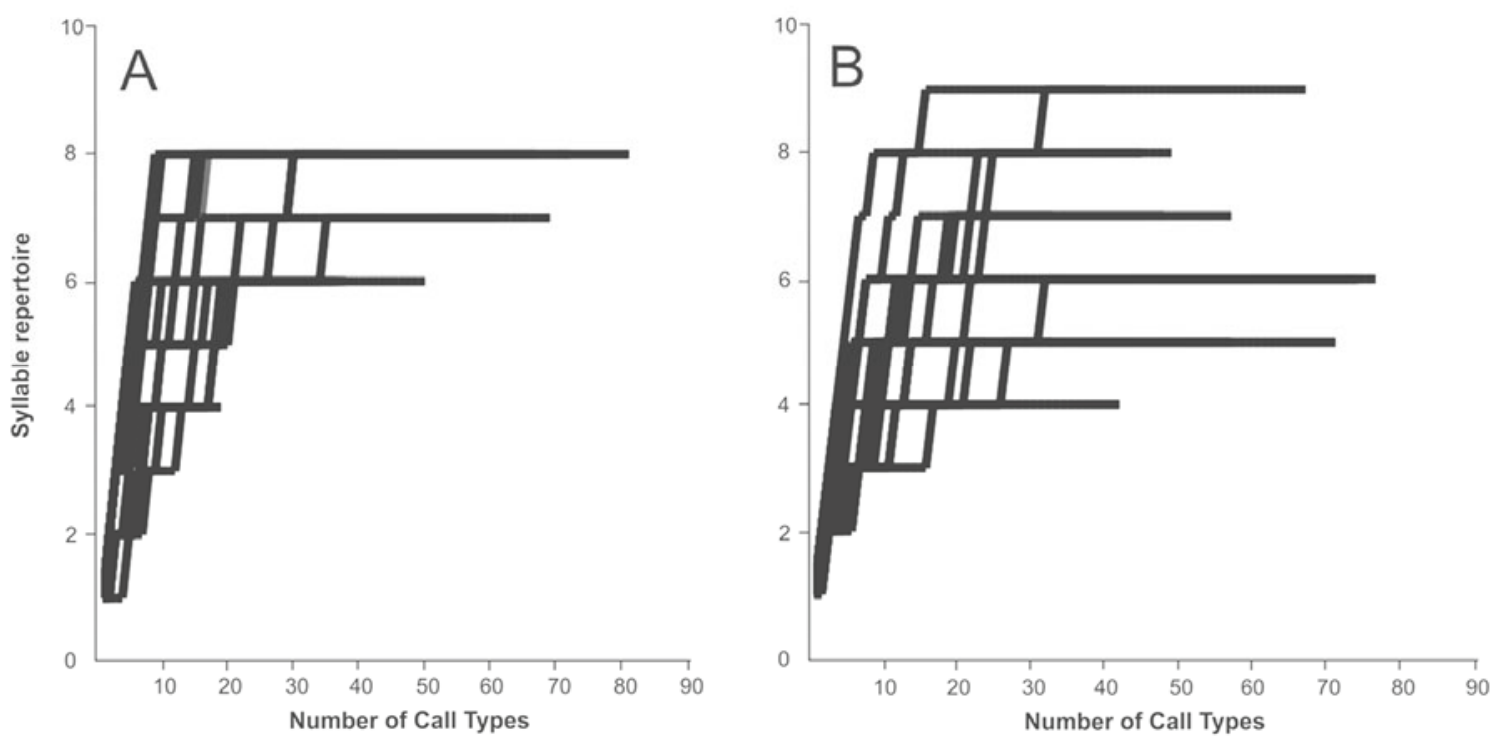

Figure 2. Call type repertoire size and accumulation functions for each individual in the sample of female Sporophila hypoxantha ( $n$ $=35, \mathbf{A})$ and $S$. melanogaster $(n=26, \mathbf{B})$ from allopatric and syntopic breeding areas in the southern Brazilian highlands. Each line represents a different female. 
Sporophila hypoxantha, Female Call Types

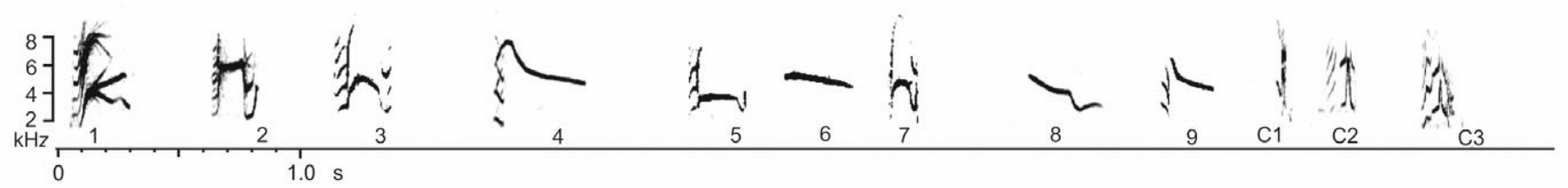

Sporophila hypoxantha, Male Call Types
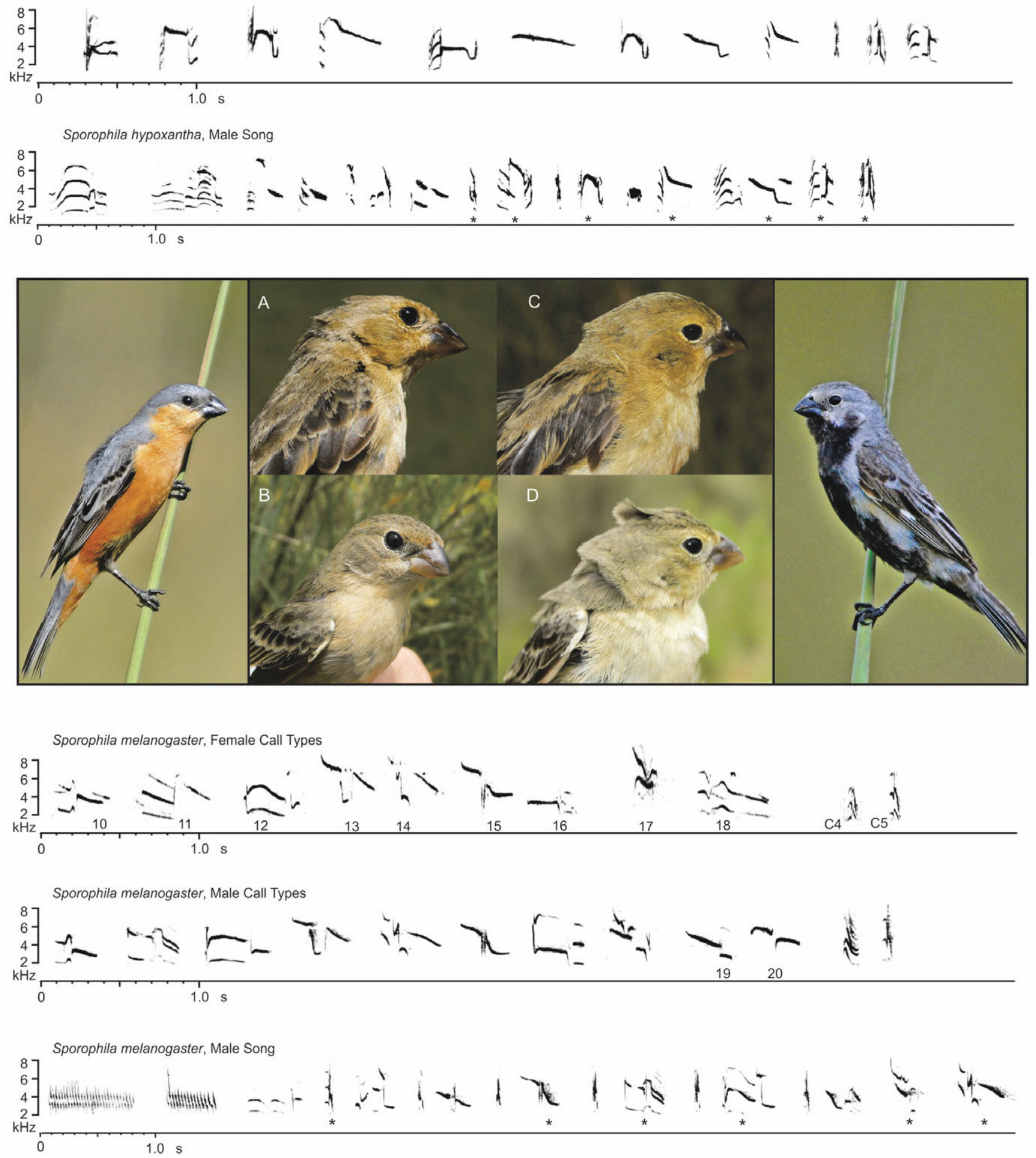

Figure 3. Call type repertoires for Sporophila melanogaster and S. hypoxantha in breeding areas in the southern Brazilian highlands. Call types are labeled by ordinal numerals and chirps with a " $\mathrm{C}$ " associated with a numeral (see mp3 files in supporting information). (A) Breeding females of $S$. hypoxantha in formative plumage and (B) definitive plumage; (C) S. melanogaster in formative plumage and (D) definitive plumage. Definitive plumage: typical adult male S. hypoxantha (left) and S. melanogaster (right). 


\section{Bray-Curtis Cluster Analysis (Single Links)}

S. melanogaster male
S. melanogaster female
S. hypoxantha male
S. hypoxantha female
* Contact Zone

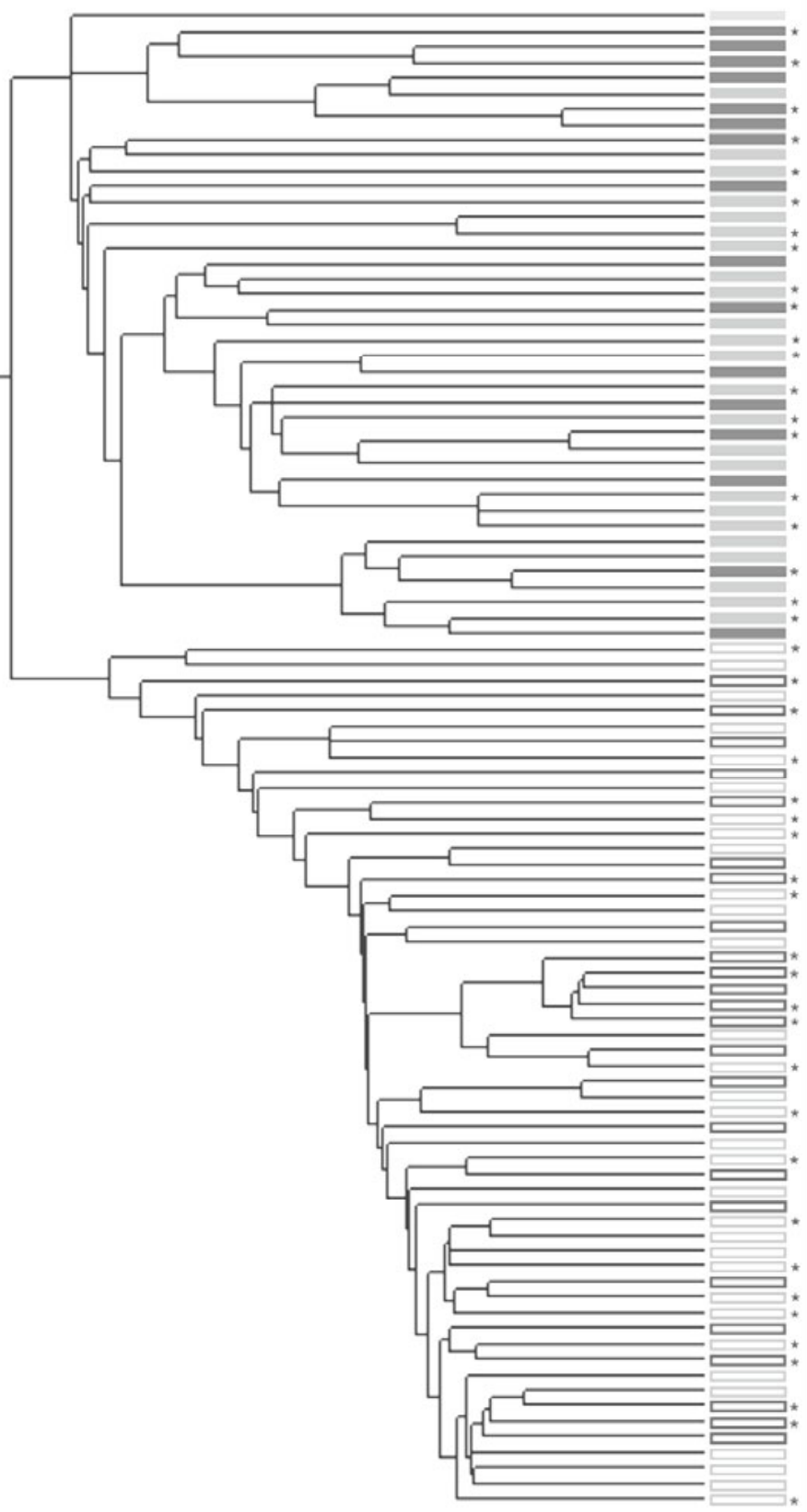

Figure 4. Similarities between the call type repertoires of Sporophila melanogaster and S. hypoxantha females and males of breeding populations in southern Brazil, based on Bray-Curtis Cluster Analysis.

\section{DISCUSSION}

We provide the first substantial evidence that voices are useful for species-level determination of female capuchino seedeaters in the field, as supported by several lines of evidence. First, we found no sharing (introgression) in call type repertoires of females of $S$. melanogaster and $S$. hypoxantha. Second, males and females of both species use the same call type repertoire as contact voices. Finally, call type repertoires seem to be a more stable signal than color plumage patterns in females and males of these two species (pers. obs.).
We observed few changes in the shape of notes, but found no cogent cluster that suggest sexual differentiation. The sound degradation hypothesis can explain the subtle variations in calls between the sexes in passerines (Searcy \& Brenowitz 1988, Ratcliffe \& Otter 1996, Collins 1999). This phenomenon has been reported for songs of $S$. melanogaster and S. hypoxantha when temporal variation was documented in note types (Repenning et al. 2010b, Areta \& Repenning 2011). Conservatively, it makes sense that sound degradation in capuchino calls should occur in parallel in both sexes, especially because of the preserved homology in their note shapes over time. 
We highlight that results presented in this study are a more reliable and less complex way to discriminate between species of capuchino females than previous attempts, which involved visually modeling UVwavelength separation (Benites et al. 2010), and which is operationally complex. Additionally, we observed evidence of variation in the extent of female plumage coloration (primarily by age) within these capuchino species. When comparing first-year females (formative plumage) of $S$. melanogaster and $S$. hypoxantha, they look more similar to each other than when comparing a first-year female with a co-specific female in a different plumage cycle (e.g., formative $v$ s. definitive plumage) (Fig. 3). This observation illustrates the complexity of relying on the use of plumage parameters for identification of capuchino females. Concerning plumage similarities, we also highlight that there is evidence showing that the measurement of plumage color reflectance in the laboratory/museum may be less reliable as compared to that on live birds captured in the field (Doucet \& Hill 2009, Hubbard et al. 2017).

In comparison, with some experience (i.e., an ability to distinguish between capuchino calls), one can widely improve their ability to detect and identify visually identical females in the field. However, unlike the relatively pure, long and very distinctive capuchino male songs, female contact calls across species are very short and may sound extremely similar to the human ear. Hence, the sonogram is a valuable tool for seeing and, in turn, hearing the complexities of these short vocalizations. In addition, using slow-speed playback appeared effective to learn how to listen to the very fast pitch changes of the vocalizations. By following such steps in the process of sound analysis, we will enhance our understanding of the extension of cospecific communication of the studied species, and even that of other capuchino species that are difficult to identify.

We found that females of each species have fully distinct contact call types, and as do males, females of different species sing different songs (Repenning et al. 2010b). Although we initially suspected there was a certain degree of introgression in the $S$. hypoxantha and $S$. melanogaster voice elements, it was not confirmed even in syntopic populations. Additionally, we did not find females with a repertoire of $S$. melanogaster coupled with $S$. hypoxantha males or vice versa, revealing there is nonrandom mating (Servedio 2004). This observation suggests that capuchinos present positive assortative mating with concordant intra-specific, sex-based call type repertoires and no mixed pairing (Randler 2002). In this scenario, social calls should play an important role in specific mate recognition between recently diverged taxa (Searby \& Jouventin 2004).

The relationships between songs and calls and how song is derived from calls varies among songbirds
(Baptista 1996). Capuchino call types could be innate elements (begging calls that develop into social calls) of their vocalization or inherently learnt from their cospecific calls (Groth 1993, Hughes et al. 1998, Riebel 2003). In addition, a considerable number of female call types (half) are composed of advertising male song. These traits may be favorable to transmit species-specific sound signals long distances, when the breeding season starts (Riebel 2003, Catchpole \& Slater 2008). These vocal systems seem to contribute to a favorable co-specific acoustic environment in the process of assortative mating (Béguin et al. 1998, Baptista \& Kroodsma 2001). This scenario would induce birds to breed near their natal areas because oscine female sexual imprinting occurs on familiar songs of her natal population (Irwin \& Price 1999, Nelson 2000, MacDougall-Shackleton et al. 2001).

Which signals would be more important in isolating populations or species? This is a recurrent question in studies on the evolution of prezygotic isolation (Brelsford \& Irwin 2009). For capuchino seedeaters, contact calls are likely to play a key role in the isolation process, since they are more concordant and stable signals for communication between them. Vocal communication appears to be the first signal during the species-specific mate recognition process among capuchino seedeaters, since concordance in voice might influence females to select males that sing dialects of the female's birthplace. Moreover, the quality or differences of male plumage coloration could be a secondary visual signal, more associated with male-male competition (Searcy \& Nowicki 2000, Byers \& Kroodsma 2009) in the process of intra-specific sexual selection. Paradoxically, we highlight that vocal and male plumage divergences did not completely prevent interbreeding between these two species, because putative hybrid males have been recorded in contact zones. Nevertheless, we attribute rape behavior as the primary cause of interbreeding between these two species, which has been occasionally observed in areas of syntopy (pers. obs.).

Finally, based on strong evidence of differentiation among closely-related capuchino females, we suggest rigorous field song-call recording followed by spectrogram analyses of the call type repertoires for species-level diagnosis and to solve the cryptic female discrimination problem. Our analysis, in addition to visual modeling for reflectance quantification of female plumage (Benites et al. 2010), reinforces the human sensorial limitation bias for accurately distinguishing capuchino females. We encourage a similar evaluation for other species or populations of capuchino seedeaters with independent trajectories and ongoing speciation across a wide geographic area as possible. Populations also can be identified by their call notes, as in other oscine passerines (Groth 1993), even when they are in their wintering areas (Areta 2012). 
The improvement of this kind of research would have positive implications for taxonomy, evolutionary and behavioral ecology studies in Neotropical seedeaters. From a conservation perspective, the identification of species-specific calls and songs can be a useful tool for conservation of threatened capuchino species, since it can help in the identification of specimens illegally captured in nature and in female-like plumage.

\section{ACKNOWLEDGEMENTS}

We thank the Brazilian Federal Agencies (CNPq and CAPES) for a scholarship to M.R. and funds to CSF, and Fundação Grupo Boticário de Proteção à Natureza (FBPNproject No. 0795-20082) and Neotropical Grassland Conservancy (NGC) for financial support; Ministério do Meio Ambiente (MMA), Pontificia Universidade Católica do Rio Grande do Sul (PUCRS) for logistical support. The study was covered by licenses from National Center for Research on the Conservation of Wild Birds (CEMAVE, No. 361788) and a permit from ICMBio by the Brazilian System and Information on Biodiversity (SISBIO, No. 1310 and No. 36881). We are grateful to Luisa F. Reis, Leandro Bugoni and Alex Jahn for correcting the English text.

\section{REFERENCES}

Areta J.I. 2008. Entre Ríos Seedeater (Sporophila zelichi): a species that never was. Journal of Field Ornithology 79: 352-363.

Areta J.I. 2012. Winter songs reveal geographic origin of three migratory seedeaters (Sporophila spp.) in southern Neotropical grasslands. Wilson Journal of Ornithology 124: 688-697.

Areta J.I. \& Repenning M. 2011. Systematics of the Tawny-bellied Seedeater (Sporophila hypoxantha) I: geographic variation, ecology, and evolution of vocalizations. Condor 113: 664-677.

Areta J.I., Noriega J.I., Pagano L. \& Roesler I. 2011. A new Blackcollared form of capuchino (Sporophila: Aves), and systematics of the Dark-throated Seedeater (S. ruficollis). Bulletin of the British Ornithologists' Club 131: 4-23.

Baptista L.F. 1996. Nature and its nurturing in avian vocal development, p. 39-60. In: Kroodsma D.E. \& Miller E.H. (eds.). Ecology and evolution of acoustic communication in birds. Ithaca: Comstock Publishing Associates.

Baptista L.F. \& Kroodsma D.E. 2001. Avian bioacoustics, p. 11-52. In: del Hoyo J., Elliott A. \& Sargatal J. (eds.). Handbook of the birds of the world, v. 6 (mousebirds to hornbills). Barcelona: Lynx Editions.

Béguin N., Leboucher G. \& Kreutzer M. 1998. Sexual preferences for mate song in female canaries. Behaviour 135: 1185-1196.

Benites P., Eaton M.D., Lijtmaer D.A., Lougheed S.C. \& Tubaro, P.L. 2010. Analysis from avian visual perspective reveals plumage colour differences among females of capuchinos seedeaters (Sporophila). Journal of Avian Biology 41: 597-602.

Bioacoustic Research Program. 2004. Raven Pro: interactive sound analyses software (version 1.5). Ithaca: Cornell Lab of Ornithology.

Brelsford A. \& Irwin D.E. 2009. Incipient speciation despite little assortative mating: the Yellow-rumped Warbler hybrid zone. Evolution 63: 3050-3060.
Bremond J.C. 1976. Specific recognition in the song of Bonelli's Warbler (Phylloscopus bonelli). Behaviour 58: 99-116.

Burns K.J., Shultz A.J., Title P.O., Mason N.A., Barker F.K., Klicka J., Lanyon S.M. \& Lovette I.J. 2014. Phylogenetics and diversification of tanagers (Passeriformes: Thraupidae), the largest radiation of Neotropical songbirds. Molecular Phylogenetics and Evolution 75: 41-77.

Byers B.E. \& Kroodsma D.E. 2009. Female mate choice and songbird song repertoires. Animal Behaviour 77: 13-22.

Campagna L., Lijtmaer D.A., Kerr K.C.R., Barreira A.S., Hebert P.D.N., Lougheed S.C. \& Tubaro P.L. 2010. DNA barcodes provide new evidence of a recent radiation in the genus Sporophila (Aves: Passeriformes). Molecular Ecology Resources 10: 449-458.

Campagna L., Gronau I., Silveira L.F., Siepel A. \& Lovette I.J. 2015. Distinguishing noise from signal in patterns of genomic divergence in a highly polymorphic avian radiation. Molecular Ecology 24: 4238-4251.

Campagna L., Repenning M., Silveira L.F., Fontana C.S., Tubaro P.L. \& Lovette I.J. 2017. Repeated divergent selection on pigmentation genes in a rapid finch radiation. Science Advances 3: e1602404.

Catchpole C.K. \& Slater P.J.B. 2008. Bird song: biological themes and variations. Cambridge: Cambridge University Press.

Collins S.A. 1999. Is female preference for male repertoires due to sensory bias? Proceedings of the Royal Society of London B: Biological Sciences 266: 2309-2314.

Di Giacomo A.S. \& Kopuchian C. 2016. Una nueva especie de capuchino (Sporophila: Thraupidae) de los Esteros del Iberá, Corrientes, Argentina. Nuestras Aves 61: 3-5.

Doucet S.M. \& Hill G.E. 2009. Do museum specimens accurately represent wild birds? A case study of carotenoid, melanin, and structural colours in Long-tailed Manakins Chiroxiphia linearis. Journal of Avian Biology 40: 146-156.

Fontana C.S. \& Repenning M. 2014. Black-bellied Seedeater (Sporophila melanogaster) In: Schulenberg T.S. (ed.). Neotropical birds online. Ithaca: Cornell Lab of Ornithology. http:// neotropical.birds.cornell.edu/portal/species/overview?p_p_ spp $=627596$ (Access on 24 July 2019).

Franz I. \& Fontana C.S. 2013. Breeding biology of the Tawny-bellied Seedeater (Sporophila hypoxantha) in southern Brazilian upland and grasslands. Wilson Journal of Ornithology 125: 280-292.

Groth J.G. 1993. Call matching and positive assortative mating in Red Crossbills. Auk 110: 398-401.

Hagemeyer N.D.G., Sturge R.J., Omland K.E. \& Price J.J. 2012. Incomplete song divergence between recently diverged taxa: syllable sharing by Orchard and Fuertes' Orioles. Journal of Field Ornithology 83: 362-371.

Horn A.G. \& Falls J.B. 1996. Categorization and the design of signals: the case of song repertoires, p. 121-134. In: Kroodsma D.E. \& Miller E.H. (eds.). Ecology and evolution of acoustic communication in birds. Ithaca: Comstock Publishing Associates.

Hubbard J.K., Hund A.K., Levin I.I., McGraw K.J., Wilkins M.R. \& Safran R.J. 2017. The importance of cross-validation, accuracy, and precision for measuring plumage color: a comment on Vaquero-Alba et al. (2016). Auk 134: 34-38.

Hughes M., Nowicki S. \& Lohr B. 1998. Call learning in Blackcapped Chickadees (Parus atricapillus): the role of experience in the development of "chick-a-dee" calls. Ethology 104: 232-249.

Irwin D.E. 2000. Song variation in an avian ring species. Evolution 54: 998-1010.

Irwin D.E. \& Price T. 1999. Sexual imprinting, learning and speciation. Heredity 82: 347-354.

Lynch A. 1996. The population memetics of birdsong, p. 181-195. In: Kroodsma D.E. \& Miller E.H. (eds.). Ecology and evolution of acoustic communication in birds. Ithaca: Comstock Publishing Associates.

MacDougall-Shackleton S.A., MacDougall-Shackleton E.A. \& Hahn 
T.P. 2001. Physiological and behavioural responses of female mountain White-crowned Sparrows to natal - and foreign dialect songs. Canadian Journal of Zoology 79: 325-333.

McAleece N., Gage J.D.G., Lambshead P.J.D. \& Paterson G.L.J. 1997. BioDiversity Pro: professional statistics analysis software. London: Scottish Association for Marine Science and Natural History Museum.

Meyer de Schauensee R.M. 1952. A review of the genus Sporophila. Proceedings of the Academy of Natural Sciences of Philadelphia 54: 153-198.

Nelson D.A. 2000. A preference for own-subspecies' song guides vocal learning in a song bird. Proceedings of the National Academy of Science of the United States of America 97: 13348-13353.

Odom K.J. \& Benedict L. 2018. A call to document female bird songs: applications for diverse fields. Auk 135: 314-325.

Ouellet H. 1992. Speciation, zoogeography and taxonomic problems in the Neotropical genus Sporophila (Aves: Emberizinae). Bulletin of the British Ornithologists' Club 112a: 225-235.

Paterson H.E.H. 1985. The recognition concept of species, p. 2129. In: Vrba E.S. (ed.). Species and speciation. Pretoria: Transvaal Museum Monographs.

Price T.D. 2008. Speciation in birds. Greenwood Village: Roberts and Company.

Randler C. 2002. Avian hybridization, mixed pairing and female choice. Animal Behaviour 63: 103-119.

Ratcliffe L. \& Otter K. 1996. Sex differences in song recognition, p. 339-355. In: Kroodsma D.E. \& Miller E.H. (eds.). Ecology and evolution in acoustic communication in birds. Ithaca: Comstock Publishing Associates.

Repenning M., Rovedder C.E. \& Fontana C.S. 2010a. Distribuição e biologia de aves nos campos de altitude do sul do Planalto Meridional Brasileiro. Revista Brasileira de Ornitologia 18: 283306.

Repenning M., Rovedder C.E. \& Fontana C.S. 2010b. Another color morph of Sporophila Seedeater from capuchinos group (Aves, Emberizidae). Iheringia: Série Zoologia 100: 369-378.

Ridgely R.S. \& Tudor G. 1989. The birds of South America, v. 1. Austin: University of Texas Press.

Riebel K. 2003. The "mute" sex revisited: vocal production and perception learning in female songbirds. Advances in the Study of Behavior 33: 49-86.

Rising J., Jaramillo A., Copete J.L. Madge S.C. \& Ryan P.G. 2011. Family Emberizidae (buntings and New World sparrows), p. 492709. In: del Hoyo J., Elliott A. \& Christie D.A. (eds.). Handbook of the birds of the world, v. 16 (tanagers to New World blackbirds). Barcelona: Lynx Editions.

Roos A.L. 2010. Capturando aves, p. 77-104. In: Matter S.V., Straube F.C., Accordi I.A., Piacentini V.Q. \& Cândido-Jr. J.F. (eds.). Ornitologia e conservação: ciência aplicada, técnicas de pesquisa e levantamento. Rio de Janeiro: Technical Books.

Searby A. \& Jouventin P. 2004. How to measure information carried by a modulated vocal signature? Journal of the Acoustical Society of America 16: 3192-3198.

Searcy W.A. \& Brenowitz E.A. 1988. Sexual differences in species recognition of avian song. Nature 332: 152-154.

Searcy W.A. \& Nowicki S. 2000. Male-male competition and female choice in the evolution of vocal signaling, p. 301-315. In: Amundsen T., Espmark Y. \& Rosenqvist G. (eds.). Animal signals: signalling and signal design in animal communication. Trondheim: Tapir Press.

Servedio M.R. 2004. The evolution of premating isolation: local adaptation and natural and sexual selection against hybrids. Evolution 58: 913-924.

Short-Jr. L.L. 1969. Relationships among some South American seedeaters (Sporophila), with a record of S. hypochroma for Argentina. Wilson Bulletin 81: 216-219.

Sick H. 1963. Hybridization in certain Brazilian Fringillidae (Sporophila and Oryzoborus). Proceedings of the International Ornithological Congress 13: 161-170.

Sick H. 1967. "Bico de Ferro": overlooked seedeater from Rio de Janeiro (Sporophila, Fringillidae, Aves). Anais da Academia Brasileira de Ciências 39: 307-314.

Sick H. 1997. Ornitologia brasileira. Rio de Janeiro: Nova Fronteira.

Slabbekoorn H. \& Smith T.B. 2002. Bird song, ecology and speciation. Philosophical Transactions of the Royal Society of London B: Biological Sciences 357: 493-503.

Associate Editor: Gustavo S. Cabanne. 